\title{
Long-term Trends in Fertility of Soils under Continuous Cultivation and Cereal Cropping in Southern Queensland. III* Distribution and Kinetics of Soil Organic Carbon in Particle-size Fractions
}

\author{
R. C. Dalal and R. J. Mayer \\ Queensland Wheat Research Institute, Department of Primary Industries, Toowoomba, Qld 4350.
}

\begin{abstract}
Distribution of soil organic carbon in sand-, silt- and clay-size fractions during cultivation for periods ranging from 20 to 70 years was studied in six major soils used for cereal cropping in southern Queensland. Particle-size fractions were obtained by dispersion in water using cation exchange resin, sieving and sedimentation. In the soils' virgin state no single particle-size fraction was found to be consistently enriched as compared to the whole soil in organic $\mathrm{C}$ in all six soils, although the largest proportion $(48 \%)$ of organic $\mathrm{C}$ was in the clay-size fraction; silt and sand-size fractions contained remaining organic $\mathrm{C}$ in equal amounts.

Upon cultivation, the amounts of organic $\mathrm{C}$ declined from all particle-size fractions in most soils, although the loss rates differed considerably among different fractions and from the whole soil. The proportion of the sand-size fraction declined rapidly (from $26 \%$ to $12 \%$ overall), whereas that of the clay-size fraction increased from $48 \%$ to $61 \%$ overall. The proportion of silt-size organic $\mathrm{C}$ was least affected by cultivation in most soils. It was inferred, therefore, that the sand-size organic matter is rapidly lost from soil, through mineralization as well as disintegration into silt-size and clay-size fractions, and that the clay fraction provides protection for the soil organic matter against microbial and enzymic degradation.
\end{abstract}

\section{Introduction}

Long-term cultivation for cereal cropping leads to a substantial loss of organic matter. Dalal and Mayer (1986a) observed a mean decrease of $19-45 \%$ in organic matter of six soil series for a cultivation period ranging from 20 to 70 years. The rate of loss of soil organic $C$ varied from 0.065 to $1.224 \mathrm{t} \mathrm{ha}^{-1} \mathrm{dm}^{-1}$ year $^{-1}$ (Dalal and Mayer 1986b). Soil properties significantly associated with the rate of loss of organic $\mathrm{C}$ were organic $\mathrm{C} /$ urease activity ratio, aggregation index and clay content. The association of organic $\mathrm{C}$ with clay may therefore be an important mechanism of organic matter protection in cultivated soil (Oades and Ladd 1977).

Tiessen and Stewart (1983) observed that the redistribution of soil organic matter between sand, silt and clay fractions occurred with a rapid loss of 'labile' fractions and enrichment of silt (Ladd et al. 1977; Turchenek and Oades 1979) and coarse clay $(2-0 \cdot 2 \mathrm{~mm})$. The loss of a 'labile' fraction could be greater than that assessed from the loss of total soil organic matter upon cultivation. To provide a better understanding of the dynamics of soil fertility under long-term cultivation the distribution and kinetics of organic $\mathrm{C}$ associated with different particle sizes in six major soils of southern Queensland were studied. 


\section{Materials and Methods}

The study area (between $27^{\circ}$ and $30^{\circ} \mathrm{S}$. and $148^{\circ}$ and $152^{\circ} \mathrm{E}$.), soils, crop and soil management practices, and soil sampling and analytical techniques were described previously (Dalal and Mayer $1986 a$ ). Mean values of sand, silt and clay contents of the soils from virgin sites $(0-0.1 \mathrm{~m}$ depth) are given in Table 1 .

Table 1. Particle-size analysis of the soils $(0-0 \cdot 1 \mathrm{~m}$ depth): mean values from virgin sites

\begin{tabular}{|c|c|c|c|c|}
\hline $\begin{array}{l}\text { Soil series } \\
\text { (No. of sites) }\end{array}$ & Great Soil Group & Sand & $\begin{array}{l}\text { Silt } \\
(\%)\end{array}$ & Clay \\
\hline Waco clay (5) & Black earth ${ }^{A}$ & $13 \cdot 2$ & $14 \cdot 4$ & $72 \cdot 4$ \\
\hline Langlands-Logie clay (6) & G.B.R. clays (brigalow) ${ }^{B}$ & $34 \cdot 8$ & $15 \cdot 8$ & $49 \cdot 4$ \\
\hline Cecilvale clay (7) & G.B.R. clays (poplar box) ${ }^{B}$ & $44 \cdot 2$ & $15 \cdot 3$ & $40 \cdot 5$ \\
\hline Billa Billa loamy clay (7) & G.B.R. clays (belah) ${ }^{\mathrm{B}}$ & $47 \cdot 9$ & $17 \cdot 9$ & $34 \cdot 2$ \\
\hline Thallon clay (6) & G.B.R. clays (coolibah) ${ }^{\text {B }}$ & $17 \cdot 7$ & $22 \cdot 8$ & $59 \cdot 5$ \\
\hline Riverview sandy loam (5) & Red earth ${ }^{C}$ & $72 \cdot 6$ & $9 \cdot 3$ & $18 \cdot 1$ \\
\hline
\end{tabular}

A Typic Pellusterts. ${ }^{B}$ Grey, brown and red clays, Typic Chromusterts.

${ }^{\mathrm{C}}$ Rhodic Paleustalfs.

\section{Particle-size Fractionation}

The soil dispersion procedure was similar to that described by Edwards and Bremner (1965). Briefly, $25 \mathrm{~g}$ air-dried soil and $16 \mathrm{~g} \mathrm{Amberlite} \mathrm{IR-120} \mathrm{cation} \mathrm{exchange} \mathrm{resin} \mathrm{(cation} \mathrm{exchange} \mathrm{capacity,} 37 \mathrm{C} \mathrm{g}^{-1}$ ) were shaken in $150 \mathrm{ml}$ of deionized water in a $250 \mathrm{ml}$ cylindrical, wide-mouthed, screw-topped bottle of pliable polyethylene (to minimize mechanical abrasion) in an end-over-end shaker for $16 \mathrm{~h}$ at $20^{\circ} \mathrm{C}$. Coarse sand was separated by sieving the dispersed soil suspension through a $0.2 \mathrm{~mm}$ sieve. The suspended clay and silt-size particles, along with the washings $(850 \mathrm{ml})$ of any adhered particles on the sieve, were collected in a 1.51 . Perspex cylinder and made up to $1250 \mathrm{ml}$ with deionized water. Silt and clay and clay fractions $(<2 \mu \mathrm{m})$ were obtained by sedimentation and the pipette method (Day 1965). The aliquots were taken in $400 \mathrm{ml}$ conical beakers, dried at $80^{\circ} \mathrm{C}$ for $24-48 \mathrm{~h}$ and weighed to determine silt and clay and clay contents; silt content $(2-20 \mu \mathrm{m})$ was determined by difference. Sand content $(0.02-2 \mathrm{~mm})$ was determined by difference in total soil weight and silt and clay contents, and also directly following the removal of resin from sand fractions with repeated flotation in deionized water. The recoveries were almost complete $(98 \pm 2 \%)$.

\section{Particle-size Organic C Determination}

Organic $\mathrm{C}$ contents of clay fractions and silt and clay fractions were determined by the Walkley and Black method adapted for spectrophotometric determination (Sims and Haby 1971). Organic C contents of the silt- and sand-size fractions were calculated by difference:

Silt-size organic $C(\%)=[($ silt- and clay-size organic $C(\%) \times$ silt and clay content $(\%))-($ clay-size organic C $(\%) \times$ clay content $(\%))] /$ silt content $(\%)$;

Sand-size organic $C(\%)=[($ total soil organic C $(\%) \times 100)-($ silt- and clay-size organic C $(\%) \times$ silt and clay content $(\%)] /$ sand content $(\%)$.

Preliminary studies on the recovery of total soil organic $C$ in sand-size fractions $(0.02-2 \mathrm{~mm})$ and silt- and clay-size fractions varied from 95 to $110 \%$ (mean value, 105\%); generally the organic $C$ content of the sand-size fraction was slightly underestimated by the difference method. It is possible that better chromic acid oxidation of organic $\mathrm{C}$ in dispersed silt- and clay-size particles was achieved than with the whole soil.

The proportion of organic $\mathrm{C}$ in clay-size, silt-size and sand-size fractions on weight/volume basis was calculated from the total soil organic $\mathrm{C}$ values, adjusted for changes in bulk density upon cultivation (Dalal and Mayer 1986a, 1986b).

Appropriate controls were run during particle-size fractionation and organic $\mathrm{C}$ analyses. Mean values of duplicate results (within $\pm 5 \%$ of the mean) are reported in this paper. 


\section{Results}

\section{Organic C Concentrations of Sand-, Silt- and Clay-size Fractions in Virgin Soils}

In virgin soils, silt was consistently enriched as compared to the whole soil in organic $C$ in all six soils (Table 2). The organic $C$ concentrations of the silt-size fractions exceeded those of sand-size and clay-size fractions in four soils (Waco, Langlands-Logie, Cecilvale and Billa Billa). In the other two soils, highest organic $\mathrm{C}$ concentrations were that of sand-size fraction in Thallon soil and clay-size fraction in Riverview soil.

Table 2. Organic $\mathbf{C}$ concentrations of different particle-size organic matter from six soil series $(0-0 \cdot 1 \mathrm{~m}$ depth): mean values from virgin sites

\begin{tabular}{|c|c|c|c|c|}
\hline \multirow{2}{*}{ Soil series } & \multicolumn{4}{|c|}{ Organic $\mathrm{C}$ concentration $(\%)$} \\
\hline & Whole soil & Sand & Silt & Clay \\
\hline Waco & $1 \cdot 63$ & $2 \cdot 25$ & $3 \cdot 90$ & $1 \cdot 16$ \\
\hline Langlands-Logie & $2 \cdot 23$ & $2 \cdot 16$ & $3 \cdot 21$ & $1 \cdot 96$ \\
\hline Cecilvale & $1 \cdot 73$ & $1 \cdot 08$ & $3 \cdot 35$ & $2 \cdot 00$ \\
\hline Billa Billa & $1 \cdot 48$ & $0 \cdot 76$ & $2 \cdot 49$ & $2 \cdot 05$ \\
\hline Thallon & $0 \cdot 77$ & $1 \cdot 09$ & $1 \cdot 02$ & $0 \cdot 73$ \\
\hline Riverview & $1 \cdot 28$ & $0 \cdot 58$ & $2 \cdot 60$ & $3 \cdot 02$ \\
\hline
\end{tabular}

Generally, organic $C$ concentrations in a particle-size fraction decreased with the increase in its content in these soils. For example, clay-size organic $\mathrm{C}$ concentration of Waco soil (clay content, $72 \cdot 4 \%$ ) was only $38 \%$ that of Riverview soil (clay content, $18 \cdot 1 \%$ ). This trend was the result of a similar partitioning for all soils of organic $C$ among the size fractions (Table 3 ). The largest proportion ( $48 \%$ overall)

Table 3. Proportion of organic $C$ in sand-, silt- and clay-size organic matter in six soil series $(0-0 \cdot 1 \mathrm{~m}$ depth): mean values from virgin sites

\begin{tabular}{lcccc}
\hline Soil series & $\begin{array}{l}\text { Whole soil } \\
\left(\mathrm{t} \mathrm{C} \mathrm{ha-} \text { hand-size C }^{-1}\right.\end{array}$ & \multicolumn{2}{c}{$\begin{array}{l}\text { Silt-size C } \\
(\% \text { of the total C) }\end{array}$} \\
\hline Waco & $13 \cdot 6$ & $18(12)^{\mathrm{A}}$ & $30(28)^{\mathrm{A}}$ & $52(59)^{\mathrm{A}}$ \\
Langlands-Logie & $22 \cdot 2$ & $31(13)$ & $25(25)$ & $44(63)$ \\
Cecilvale & $17 \cdot 5$ & $27(15)$ & $27(25)$ & $46(60)$ \\
Billa Billa & $13 \cdot 7$ & $25(7)$ & $29(32)$ & $46(62)$ \\
Thallon & $7 \cdot 4$ & $21(19)$ & $24(25)$ & $55(56)$ \\
Riverview & $15 \cdot 7$ & $33(6)$ & $20(27)$ & $47(69)$ \\
Average & & $26(12)$ & $26(27)$ & $48(61)$ \\
\hline
\end{tabular}

A Proportion of organic $\mathrm{C}$ in different particle-size fractions in cultivated soils.

of total organic $\mathrm{C}$ was present in the clay-size fraction in all soils. Silt-size and sandsize organic C accounted for $26 \%$ each. Although the proportion of silt-size organic $\mathrm{C}$ changed only slightly upon cultivation in most of these soils, those of sand-size and clay-size organic $C$ showed large changes; that of the former decreased from $26 \%$ to $12 \%$ overall, whereas that of the latter increased from $48 \%$ to $61 \%$ (Table 3). 


\section{Kinetics of Organic $C$ in Sand-, Silt- and Clay-size Fractions}

The changes in the amounts of organic $C$ in a particle-size fraction with period of cultivation were described by the exponential equation,

$$
C_{\mathrm{t}}=C_{\mathrm{e}}+\left(C_{\mathrm{o}}-C_{\mathrm{e}}\right) \exp (-k t)
$$

where $C_{\mathrm{t}}, C_{\mathrm{o}}$ and $C_{\mathrm{e}}$ are the amounts of organic $C\left(\mathrm{t} \mathrm{ha} \mathrm{d}^{-1} \mathrm{dm}^{-1}\right)$ in a particlesize fraction at cultivation period $t$ (years), initially and at equilibrium, and $k$ is the rate constant (year ${ }^{-1}$ ). The kinetic parameters of organic $C$ loss from sand-, siltand clay-size fractions are given in Table 4 for only those soils where $C_{\mathrm{o}}, C_{\mathrm{e}}$ and $k$ values were significant $(P<0 \cdot 05)$.

Fig. 1 and Table 4 show that, although the amounts of organic $C$ in all particlesize fractions declined with period of cultivation, that of the sand-size fraction generally declined most. It is likely that, at least in some soils, coarser organic

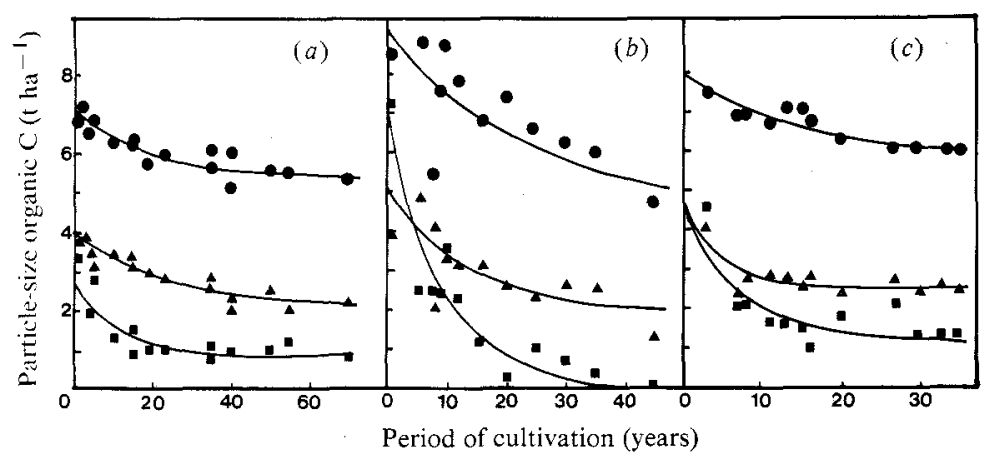

Fig. 1. Changes in the amounts of organic $\mathrm{C}(0-0.1 \mathrm{~m}$ depth) in sand-size ( $\mathbf{\square})$, silt-size $(\boldsymbol{\Lambda})$ and clay-size $(\boldsymbol{)})$ fractions with period of cultivation in $(a)$ Waco soil, (b) Langlands-Logie soil and (c) Cecilvale soil series.

Table 4. Kinetic parameters of organic $C$ loss from sand-, silt- and claysize fractions

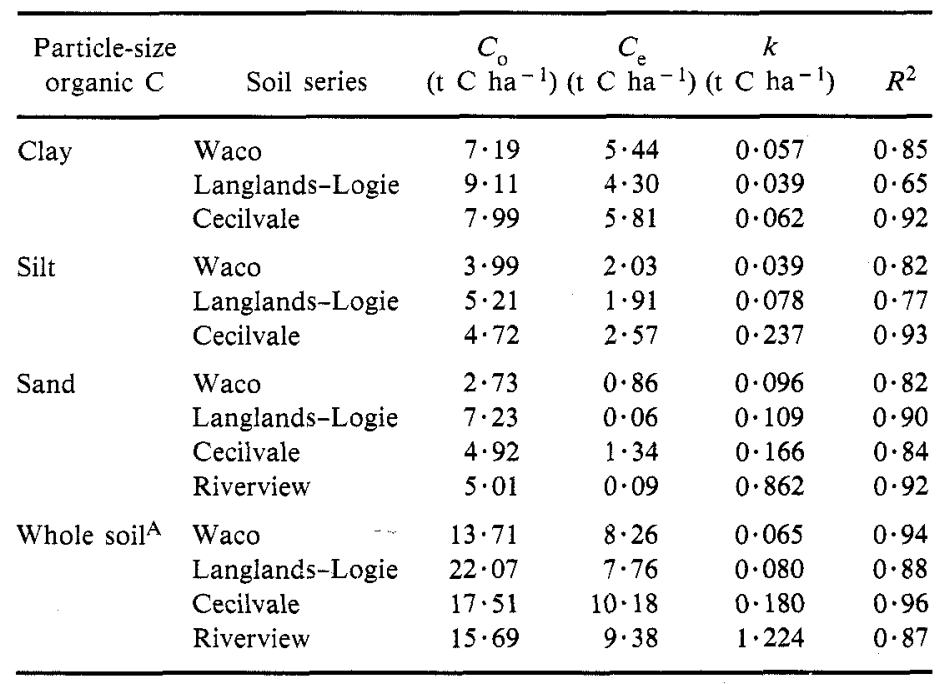

${ }^{A}$ From Table 3 (Dalal and Mayer 1986b). 
matter may have been transformed and then transferred to the finer fractions. The $k$ values of clay-size organic $\mathrm{C}$ were lower and those of the sand-size fraction were generally higher than the whole soil organic C. The $k$ values of the silt-size organic $C$, however, showed no consistent trend (Table 4).

The proportion of clay-size organic $C$ to that of the whole soil increased exponentially with period of cultivation in at least four soils (Fig. 2). The rates of

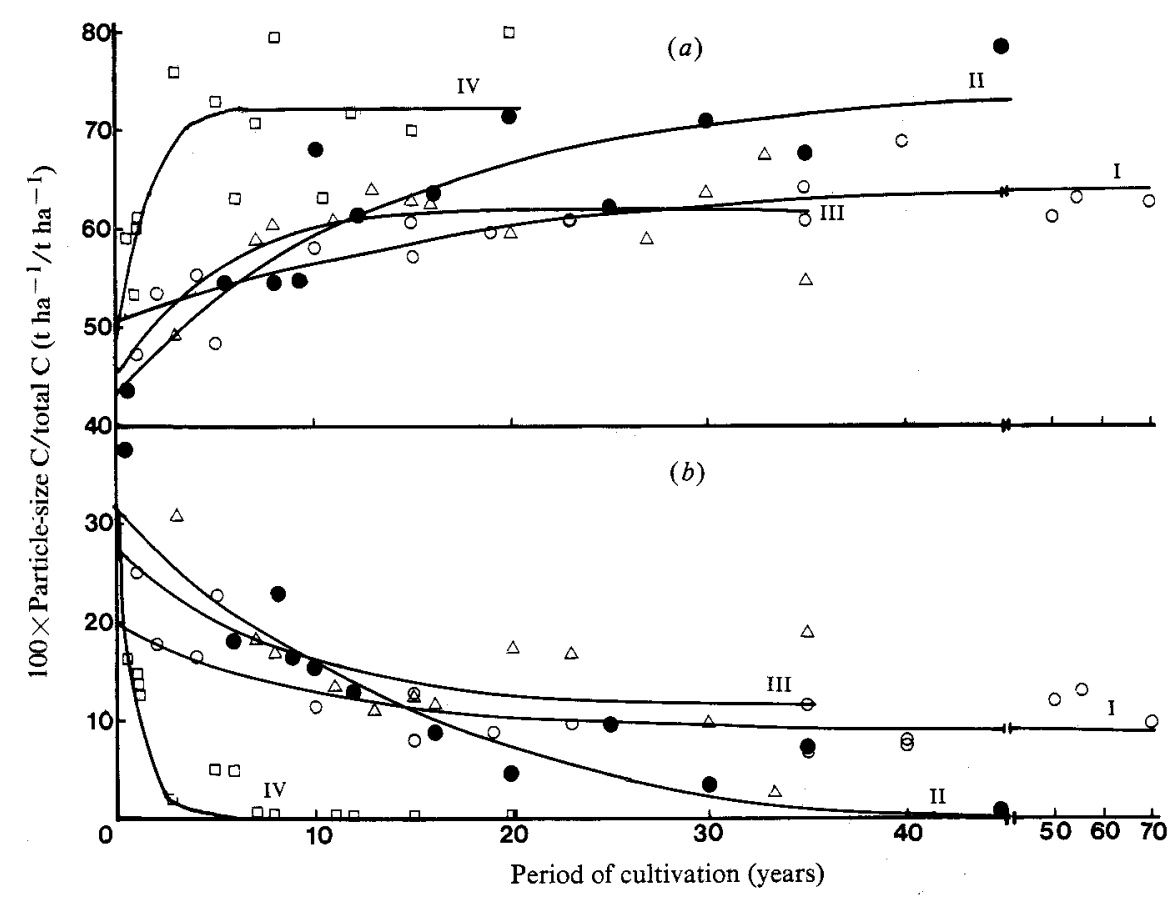

Fig. 2. Changes in the proportion of total soil organic $C$ in (a) clay-size and $(b)$ sand-size fractions with period of cultivation in four soil series. I, Waco $(O)$; II, Langlands-Logie (O); III, Cecilvale ( $\triangle$ ); IV, Riverview ( $\square$ ).

Table 5. Rate of increase in the proportion of total organic $\mathbf{C}$ in the claysize fraction upon cultivation (Clay-size $\mathrm{C} /$ total $\mathrm{C}) \times 100$

\begin{tabular}{lllll}
\hline \multicolumn{1}{c}{ Soil series } & $a^{\mathrm{A}}$ & $e^{\mathrm{A}}$ & $r^{\mathrm{A}}$ & $R^{2}$ \\
\hline Waco & 51 & 65 & 0.057 & 0.76 \\
Langlands & 43 & 75 & 0.071 & 0.84 \\
Cecilvale & 46 & 62 & 0.214 & 0.92 \\
Riverview & 47 & 72 & 0.815 & 0.76 \\
\hline
\end{tabular}

A Exponential equation: $y=e+(a-e) \exp (-r t)$, where $y, a$ and $e$ are the proportions of clay-size organic $\mathrm{C}\left(\mathrm{t} \mathrm{ha} \mathrm{a}^{-1}\right) /$ total soil organic $\mathrm{C}\left(\mathrm{t} \mathrm{ha} \mathrm{h}^{-1}\right)$ at time $t$ years of cultivation, initially and at equilibrium, respectively, and $r$ is the rate of increase (year-1).

increase in this proportion (Table 5) were significantly related to the reciprocal of the clay content of the soils $(r=0.99 *)$, presumably due to protection or inaccessibility of organic $\mathrm{C}$ provided by the clay fraction. Conversely, the proportion of sand-size organic $\mathrm{C}$ to that of the whole soil decreased with period 
of cultivation (Fig. 2). This proportion declined faster with lower rainfall $\left(r=-0 \cdot 88^{*}\right)$, presumably because of less crop residues which initially enter mostly the sand-size organic matter. The proportion of silt-size organic $\mathrm{C}$ showed no consistent trends with period of cultivation.

The ratio of rate constants $(k)$ of organic $C$ loss in particle-size fractions and the whole soil (Dalal and Mayer 1986b) for Waco, Langlands-Logie and Cecilvale showed that soils differed considerably in that ratio in any particle-size fraction (Table 6). For example, in Langlands-Logie soil the highest $k$ ratio occurred in the sand-size fraction, whereas in Cecilvale soil it was in the silt-size fraction.

Table 6. Ratio of rate constants $(k)$ of organic $C$ loss from different particle-size fractions and the whole soil

\begin{tabular}{lccc}
\hline \multicolumn{1}{c}{ Soil series } & $\frac{k \text { (sand-size C) }}{k \text { (total C) }}$ & $\frac{k \text { (silt-size C) }}{k \text { (total C) }}$ & $\frac{k \text { (clay-size C) }}{k \text { (total C) }}$ \\
\hline Waco & 1.48 & 0.60 & 0.88 \\
Langlands-Logie & 1.36 & 0.98 & 0.49 \\
Cecilvale & 0.92 & 1.32 & 0.34 \\
\hline
\end{tabular}

Therefore, the nature and extent of organic $\mathrm{C}$ association with inorganic soil constituents, as well as particle size, may influence the rate of loss of organic matter in soil.

\section{Discussion}

The particle-size separation procedure employed in this study results in complete separation of the mineral particles without the destruction or irreversible alteration of any organic materials present and without degradation of mineral colloids (Edwards and Bremner 1965, 1967). Some losses of soluble organic C due to sorption on cation exchange resin may occur, although this fraction rarely exceeds $1-2 \%$ in most soils.

The distribution of organic $C$ in different particle-size fractions was found to be similar in these soils to those reported by others (Turchenek and Oades 1979; Hinds and Lowe 1980) in that the organic C concentration in a particle-size fraction generally decreased with the increase in its total content in soil. The clay fraction contains a greater proportion of organic matter in soils over a wide range of clay contents (Chichester 1969; Hinds and Lowe 1980; Christensen and Sorensen 1985), although soils high in silt content may also contain a high proportion of organic matter in that fraction (McKeague 1971).

Greenland and Ford (1964) found that the proportion of the clay-size organic C (clay-organic complex) varied from $52 \%$ in a solonized brown soil to $98 \%$ in a lateritic red earth. On the other hand, Turchenek and Oades found only 35-52\% organic $\mathrm{C}$ in the clay fractions of red-brown earths (Rhodoxeralf), black chernozemic (Haploboroll) and ground-water rendzina (Calciaquoll) soils. Besides the effects of different separation techniques used by different workers, different environments and different cultural practices for varying periods of cultivation may account for such large differences observed in the proportion of organic $\mathrm{C}$ found in various particle-size fractions. The effect of period of cultivation on the changes in the proportion of soil organic $C$ in the sand-size and the clay-size fractions is amply demonstrated in the present study. 
The sand-size organic matter, which consists of mostly plant debris (Turchenek and Oades 1979) and probably fungal hyphae (Oades and Ladd 1977), is rapidly lost from soil, mostly due to oxidation, but also due to disintegration upon cultivation to enter silt-size or clay-size fractions (Ladd et al. 1977). In most of these soils, however, a rapid decline in sand-size organic matter during the initial period of cultivation occurred without an apparent concomitant increase in silt-size and clay-size organic matter (Fig. 1). It appears, therefore, that most of the loss in sand-size organic matter resulted from rapid mineralization, as proposed by Greenland and Ford (1964). On the other hand, some organic C, probably microbial biomass and its debris (Ladd et al. 1977), was lost even from silt- and clay-size fractions in most soils upon cultivation. It is likely that 'free' organic matter, that is, sand-size organic matter, and organic matter unassociated with siltand clay-size mineral particles, constitutes the 'labile' organic matter in soil. Thus, the rapid loss of 'labile' organic matter upon cultivation may result in greater reduction in soil fertility than is apparent from a comparison of total soil organic matter contents of virgin and cultivated soils (Tiessen and Stewart 1983) or from the rate of loss of total soil organic C (Dalal and Mayer 1986b). The studies of the dynamics of the 'labile' organic matter in soils under long-term cultivation for cereal cropping will be subsequently reported.

The rate of loss of organic $\mathrm{C}$ from the clay fraction was lower than that from the other fractions and the whole soil (Table 4), resulting in an increasing proportion of total organic $\mathrm{C}$ remaining in the clay fraction with cultivation. The clay fraction, therefore, provides protection to organic matter or makes it relatively inaccessible against microbial and enzymic attack (Dalal and Mayer 1986b). Although the proportion of total organic $\mathrm{C}$ in the silt-fraction showed no consistent trends with cultivation, because of its relatively high organic $\mathrm{C}$ concentration (Table 2), it, along with the clay-size fraction, may be important in long-term organic matter cycling in soil (Christensen and Sorensen 1985).

\section{Acknowledgments}

We are thankful for the technical assistance provided by Mrs R. Coonan for particle-size fraction and organic $\mathrm{C}$ analyses.

\section{References}

Chichester, F. W. (1969). Nitrogen in soil organo-mineral sedimentation fractions. Soil Sci. 107, 356-63. Christensen, B. T., and Sorensen, L. H. (1985). The distribution of native and labelled carbon between soil particle size fractions isolated from long-term incubation experiments. J. Soil Sci. 36, 219-29.

Dalal, R. C., and Mayer, R. J. (1986a). Long-term trends in fertility of soils under continuous cultivation and cereal cropping in southern Queensland. I. Overall changes in soil properties and trends in winter cereal yields, Aust. J. Soil Res. 24, 265-79.

Dalal, R. C., and Mayer, R. J. (1986b). Long-term trends in fertility of soils under continuous cultivation and cereal cropping in southern Queensland. II. Total organic carbon and its rate of loss from the soil profile. Aust. J. Soil Res. 24, 281-92.

Day, P. R. (1965). Particle fractionation and particle-size analysis. In 'Methods of Soil Analysis'. Part 1. (Ed. C. A. Black.) pp. 545-67. (Am. Soc. Agron.: Madison, Wis.)

Edwards, A. P., and Bremner, J. M. (1965). Dispersion of mineral colloids in soils using cation exchange resins. Nature, Lond. 205, 208-9.

Edwards, A. P., and Bremner, J. M. (1967). Dispersion of soil particles by sonic vibration. J. Soil. Sci. 18, 47-63.

Greenland, D. J., and Ford, G. W. (1964). Separation of partially humified organic materials from soils by ultrasonic dispersion. Trans. 8th Int. Congr. Soil Sci. Vol. 3, pp. 137-48. 
Hinds, A. A., and Lowe, L. E. (1980). Distribution of carbon, nitrogen, sulphur and phosphorus in particle-size separates from gleysolic soils. Can. J. Soil Sci. 60, 783-6.

Ladd, J. N., Parsons, J. W., and Amato, M. (1977). Studies of N immobilization and mineralization in calcareous soils. 2. Mineralization of immobilized $\mathrm{N}$ from soil fractions of different particle size and density. Soil Biol. Biochem. 9, 319-25.

McKeague, J. A. (1971). Organic matter in particle size and specific gravity fractions of some Ah horizons. Can. J. Soil Sci. 51, 499-505.

Oades, J. M., and Ladd, J. N. (1977). Biochemical properties - metabolism of carbon and nitrogen. In 'Soil Factors in Crop Production in Semi-Arid Environments'. (Eds J. S. Russell and E. L. Greacen.) pp. 127-60. Queensland Univ. Press: St. Lucia, Qld.)

Sims, J. R., and Haby, V. A. (1971). Simplified colorimetric determination of soil organic matter. Soil Sci. 112, 137-41.

Tiessen, H., and Stewart, J. W. B. (1983). Particle-size fractions and their use in studies of soil organic matter: II. Cultivation effects on organic matter composition in size fractions. Soil Sci. Soc. Am. J. 47, 509-14.

Turchenek, L. W., and Oades, J. M. (1979). Fractionation of organo-mineral complexes by sedimentation and density techniques. Geoderma 21, 311-43.

Manuscript received 6 May 1985, accepted 25 November 1985 